\title{
Schedule I Substance
}

National Cancer Institute

\section{Source}

National Cancer Institute. Schedule I Substance. NCI Thesaurus. Code C48672.

A category of drugs not considered legitimate for medical use. 